\title{
创建园林城市 提高园林绿化管理水平
}

\author{
肖素云
}

广西桂林市资源县园林管理所

DOI:10.32629/eep.v3i2.685

[摘 要] 随着当前人们的生活水平显著提升,对于城市内的居住环境需求也发生了一定的变化。基于此背景下,城市建设也逐渐被社会各界所 关注。对于城市的建设来说,城市中园林绿化属于核心的组成部分。园林绿化的建设与管理水平会直接影响城市的发展速度。所以,本文从创建 园林城市提高园林绿化管理水平的重要意义展开探究, 并以此为依据, 提出制定可行性目标、因地制宜开展绿化管理、加强监督检查力度等措施, 希望为相关人士提供参考与借鉴。

[关键词] 园林城市; 园林绿化管理; 监督与控制; 因地制宜

社会经济处于持续发展的阶段, 人们对生活质量的需求也不断提高, 传统的物质条件已经无法满足现代化人民的需求。在生活与居住的环境当 中, 人们更加希望能够处于美丽的园林环境当中。因此, 结合园林城市的标 准, 加快园林绿化的建设速度十分重要。只有创设良心循环的生态系统, 创建园林城市, 植树治水, 才能够达到改善城市生态环境的基础目标。在美 化城市的基础上, 打造出良好的居住环境, 以此为城市建设奠定基础, 推动 城市的经济持续发展。

\section{1 创建园林城市,提高园林绿化管理水平的重要意义}

在创建园林城市的过程中, 城市园林绿化建设更加有利于保障人们的 身心健康, 林带中种植的不同种类植物, 可以利用叶子的光合作用, 吸收掉 周围环境多余的二氧化碳, 还能有效的净化空气, 释放出更多的氧气 ${ }^{[1]}$ 。与 此同时, 还有些绿色植物能够吸附有害物质, 能够吸收与利用空气中存在 的重金属等有害的气体, 有效的避免粉尘污染与空气污染, 还能起到阻挡 城市工业与交通业的大量污染气体, 起到重要的过滤作用。植物尤其是树 木, 能够阻挡与吸附烟尘与粉尘。由于城市人口数量较多, 导致空气中蕴藏 了大量的细菌。加快城市绿化建设脚步, 能够将植物杀菌素释放出来, 并且 利用树木对声波进行散射、吸收, 在一定程度上减轻噪声的污染, 有利于人 们的身心健康。

\section{2 创建园林城市,提高园林绿化管理水平的有效措施}

2. 1 制定可行性目标, 因地制宜开展绿化管理

城市绿化属于重要的生态基础设施, 也是展示出对外形象的重要载体, 一个地区的绿化水平会直接的代表这个地区的管理水平、发展理念与文化 素养等。要想达到较高的水平, 就需要以科学发展观为核心, 并以环保优先 的原则为基础, 建立以保护环境为核心的政策指标体系, 并且以持续发展 为核心的资源环境安全保障体系 ${ }^{[2]}$ 。对于不同的地区, 都需要有不同的气 候、地质条件, 所以需要有相应的植物种类, 也需要在适宜的生态条件下开 展, 才能更加苕壮的成长, 其功能、生态、景观效果才能有效的发挥出来。 不同气候、特色的城市, 都有适合林地生长的植物群落。城市的人文特色、 历史等, 都需要恰当的植物景观进行点缀。

在城市园林绿化的过程中, 需要以生态优先的原则为基础, 确立园林 绿化的生态目标, 也就觉得了城市绿化建设在树种选择, 花卉点缀、灌木搭 配等各个方面, 改善生态环境, 不断提升生态的质量。在植物配置的过程中,
对自然的生长环境进行模拟, 并结合当地的生态环境与土地条件。在发挥 其生态效益的同时, 尽可能减少单一植物种类群落, 并在空间上进行植物 种类的搭配, 并且协调整个结构, 将三维空间的景观色彩展示出来。

2.2 结合园林文化, 加强监督检查力度

首先, 城市园林绿化属于一项促进精神文明建设与物质文明建设的重 要规工作, 还能弘扬我国优秀的传统文化, 融入文化的内涵, 将城市的发展 脉络直观的体现出来。其次, 加强对园林建设监督检查力度十分重要, 相关 的工作人员需要结合园林建设的标准, 根据相应的程序开展工作, 并采用定 人、定点与定责任的基本方式, 对植被栽种的质量进行把控, 若苗木的规格 不合理或是土球的大小没有达到基础的标准, 就不能进行栽种 ${ }^{[3]}$ 。种植土壤 的数量与质量、地形造势、打穴、打撑等工作, 如果没有做到位, 就不能进 行后续的栽种工作。如果施肥、修剪枝叶、浇水以及防病虫害等工作没有 做到位, 就不能开展园林建设工作的验收。只有秉承上述的标准, 才能保证 园林建设中植被的存活率, 以此不断扩大城市的绿化面积。最后, 对于城市 园林绿化管理的养护工作来说, 需要定期的检查, 并在年终进行考核。通过 不断强对园林养护工作的监督力度, 才能保证各项管护工作落实到实处, 以 此做好各个细节的控制, 不断提升城市的绿地管理质量, 创建园林城市。

\section{3 结束语}

总而言之, 基于城市化进程不断加速的背景下, 城市的生态环境产生 了较大的变化, 为了创设出良好的生活环境, 城市园林的绿化管理工作十 分重要。所以, 专业的管理工作人员需要做好规范化的管理与监督, 实现植 物色彩与形态的互相融合, 以此达到基础的园林绿化效果。通过创建园林 城市, 开展合理的城市绿化规划工作, 因地制宜, 从全局性与前瞻性的角度 进行规划, 以此不断提高园林绿化管理水平, 创设具体特色的城市品牌, 实 现稳定长远发展目标。

\section{[参考文献]}

[1]崔永涛.构建生态园林城市提升园林绿化管理水平[J].城市建设理 论研究:电子版,2017(06):302.

[2]张启.做好园林绿化管理 创建园林城市 [J]. 引文版:工程技 术,2015(42):236.

[3]李其庄.如何提高园林绿化工程质量管理水平[J].商品与质量:学术 观察,2012(10):342. 